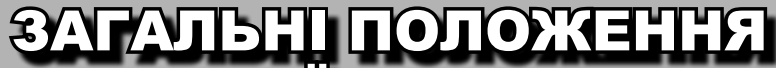 \\ CУAOBOI ERCIHPTA3A
}

UDC 343.98

Prof. Dr A. Ivanović, Deputy Director of

Forensic Center Montenegro, Permanent

Representative in ENFSI

\section{DEVELOPMENT AND COOPERATION OF FORENSIC SCIENCES IN EUROPE: CONTEMPORARY ASPECT}

This paper will present the method of standardization and accreditation of forensic work as one of the most important segments in resolving criminal offenses and detecting their perpetrators. When dealing with criminal investigations, in the case of cross-border crime, terrorism and corruption, it is of great importance to apply the evidence obtained in one country in other countries in the right way. In that direction, the paper will provide an overview of the harmonization of the performance of forensic-expert jobs in the countries of Europe, primarily related to the Decision of the EU Council 2009/905/JHA on the accreditation of forensic services and the conduct of laboratory activities in a uniform, standardized and uniform manner, for criminal-forensic investigations, as well as the European Union project The creation of a European forensic space and development of the forensic infrastructure in Europe by 2020, which will be completed in all EU countries by 2020.

Keywords: forensic science, criminal investigation, accreditation, standardization.

All states that strive to be democratic, mostly and largely rely on their own judicial system. Therefore, the judicial system in the countries of Europe can't even be imagined, let alone applied without the high quality participation of forensic science in it. Criminal charges that are not supported by quality and science and expertise based on forensic evidence are usually completed in a prosecutor's drawer, but they are not processed in one word. Also, the material traces on which the criminal complaint is based, if they are not tertiary to the quality standards that must be applied in all European countries equally, are declared invalid in the court procedure and (with the right) there is (unjust) suspicion that they have been replaced, misused, subsequently altered, obtained on non-incomplete and unresponsive devices, using chemicals and solutions that have expired, and so on! The permanent and frequent threat of cross-border crime, terrorism and corruption, as an imperative, has set the harmonization of forensic work in Europe. This is particularly true for the Member States of the European Union, which do not have mutual boundaries, and therefore also border controls. In one word, crime in the European Union knows no boundaries, but criminalistics and forensics do their 
jobs in accordance with the legal laws of each state individually. The more and more frequent cases of cross-border crime, terrorism and corruption have placed before the countries of Europe the imperative of harmonization, matching and uniformity of forensic research, testing and expert work. In this way, forensic evidence, which is precious and most importantly crucial for resolving criminal offenses and prosecuting their perpetrators, will be usable from one state to another and in this way lead to the efficiency and effectiveness of criminal investigations of cross-border crime, corruption and terrorism. Harmonization and matching of forensic research, testing and expert work in the countries of Europe is done through the ENFSI ${ }^{1}$ (Evropsko udruženje forenzičkih naučnih institucija ENFSI, engl. European Network of Forensic Science Institute).

ENFSI. At the 10th Interpol Symposium in the Field of Criminal technique, held in 1992, the idea of forming a European Association of Forensic Laboratories was launched, modeling on a similar association that exists in the United States (ASCLD-American Association of Forensic Laboratory Directors). Thus, in 1995, in Rijswik, the Netherlands, the European Association of Forensic Laboratories was established, the European Network of Forensic Science Institutes (ENFSI). Since then, the ENFSI has grown to 68 forensic laboratories from 36 European countries. It is worth mentioning that non-member countries are: Portugal (lost its membership in 2013 because it did not accredit its Forensic Laboratory until that deadline, otherwise given by the ENFSI), Bosnia and Herzegovina (also lost its membership in 2013, from the same reasons (such as Portugal), Belarus (not a member of the Council of Europe ${ }^{2}$, which is one of the requirements for ENFSI membership ${ }^{3}$ ), Moldova (applied for ENFSI membership in 2017) and Albania (so far not applied for ENFSI membership).

The membership of a forensic laboratory in the ENFSI association implies that it possesses modern equipment for work, to apply modern sophisticated and standardized methods of expertise, that employees in this laboratory are qualified to work on the mentioned devices and that they possess certificates for the application of the mentioned methods. ENFSI is recognized as a monopoly organization in forensic science in the European Union. Thus, ENFSI is a scientificprofessional association, which the European Union is tasked with developing forensics in the European Union and countries that intend to become it. Through the ENFSI, the European Union has long since begun work on harmonizing and matching forensic research, testing and expert work. Standardization of Forensic Affairs in Member States ENFSI is implemented through its Permanent Committee for Quality and Competence $\left(\mathrm{QCC}^{4}\right)$.

In order to harmonize and matching forensic affairs in Europe, the Council of the European Union on November 30, 2009 passed Decision 2009/905/JHA which refers to the accreditation of forensic institutions in the European Union.

URL: www.enfsi.eu.

URL: http://www.coe.int/fr/web/about-us/our-member-states.

URL: www.enfsi.eu.

URL: http://enfsi.eu/about-enfsi/structure/standing-committees/qcc/.

URL: http://eur-lex.europa.eu/legal-content/EN/TXT/?uri=CELEX\%3A32009F0905. 
This Decision is aimed at ensuring the reliability, compatibility and usefulness of forensic data (to start DNA profiles and fingerprints), from one country to another. In order to secure the objective set out in Council Decision 2009/905/JHA, the same obliges all EU Member States to have at least one Forensic Institution accredited to the international quality standard ISO/IEC 17025. Article 5 of the above-mentioned Council Decision implies that in order to recognize forensic testing, analysis, research and expertise, each Member State must comply with stringent requirements that meet the ISO/IEC 17025 quality standard. The implementation of the EU Council Decision in point 7 of the same imperative of the Member States requires the following:

1. Accreditation of the DNA laboratory until 30.11.2013.

2. Accreditation of dactyloscopic laboratories up to 30.112015 .

3. Inclusion in the national legislation of the EU Council Decision 2009/905/ JHA, until 30.05.2016.

4. By the end of 2018, the EU Council will exercise control over the application of this Decision in the Member States.

The implementation of the Council of Europe's Decision 2009/905/JHA was carried out through the ENFSI association in a manner that all forensic institutions, ENFSI members, had to be accredited to ISO 17025 by the end of 2013. Forensic laboratories, members of the ENFSI, who have not accredited to the ISO 17025 standard, have lost membership and have not received it so far. What this means in practice: if a citizen of a state in Europe who has a forensic institution accredited to the ISO 17025 standard is suspected and prosecuted, for example, in Portugal, Bosnia and Herzegovina, Moldova, Albania and Belarus (which have not acceded to their forensic institutions), it can file a request to the International Tribunal in the direction of the indictment, since it is not based on standardized methods guaranteed by the ISO 17025 standard. In one word, the suspected or prosecuted is not treated for forensic-investigative methods applied in his country, and the ISO 17025 standard implies that criminal-forensic investigations and evidence are obtained in this way:

- reliable;

- valid;

- based on standard procedures;

- compatible with results in other countries, other scientific-professional circles, internationally recognized institutions;

- in accordance with the evidence standards of the appropriate judicial, administrative and legal systems;

- obtained in due time, in an effective and efficient manner.

Table gives an overview of the countries of Europe that accredited their forensic laboratories and according to which standard. The data presented in Table were obtained after the research of the ENFSI Standing Committee of the Quality and Competence $(\mathrm{QCC})^{1}$.

\footnotetext{
1 URL: http://enfsi.eu/about-enfsi/structure/standing-committees/qcc/.
} 
Table

The display of the countries of Europe that accredited their forensic laboratories and according to which standard

\begin{tabular}{|l|l|}
\hline \multicolumn{1}{|c|}{ Country } & \multicolumn{1}{|c|}{ Forensic institution accredited (according to which standard) } \\
\hline Armenia & ISO 17025, ISO 9001, ISO 17065 \\
\hline Austria & ISO 17025 \\
\hline Bulgaria & ISO 17025 \\
\hline Cyprus & ISO 17025 \\
\hline Croatia & ISO 17025 \\
\hline Czechia & ISO 17025 \\
\hline Denmark & ISO 17025 \\
\hline Estonia & ISO 17025, ISO 17020 \\
\hline Finland & ISO 17025 \\
\hline France & ISO 17025 \\
\hline Georgia & ISO 17025 \\
\hline Germany & ISO 17025, ISO 17020 \\
\hline Ireland & ISO 17025 \\
\hline Italy & ISO 17025, ISO 9001 \\
\hline Latvia & ISO 17025 \\
\hline Lithuania & ISO 17025 \\
\hline Macedonia & ISO 17025 \\
\hline Montenegro & ISO 17025 \\
\hline Netherlands & ISO 17025 \\
\hline Norway & ISO 17025 \\
\hline Poland & ISO 17025 \\
\hline Romania & ISO 17025 \\
\hline Russia & ISO 17025 \\
\hline Serbia & ISO 17025 \\
\hline
\end{tabular}




\begin{tabular}{|l|l|}
\hline \multicolumn{1}{|c|}{ Country } & \multicolumn{1}{|c|}{ Forensic institution accredited (according to which standard) } \\
\hline Slovenia & ISO 17025 \\
\hline Slovakia & ISO 17025 \\
\hline Spain & ISO 17025, ISO 9001, ISO 17043 \\
\hline Sweden & ISO 17025 \\
\hline Switzerland & ISO 17025, ISO 17020 \\
\hline Turkey & ISO 17025 \\
\hline $\begin{array}{l}\text { United } \\
\text { Kingdom }\end{array}$ & ISO 17025, ISO 17043 \\
\hline Ukraine & ISO 17025 \\
\hline
\end{tabular}

For the purpose of operationalizing the conduct of criminal-forensic investigations of cross-border crime, terrorism and corruption, the Council of the European Union, at its meeting held in Brussels on 13-14 December 2011, adopted the document Creation of European forensic space and the development of forensic infrastructure in Europe by 2020, Council conclusions on the vision for European Forensic Science 2020, including the creation of a European Forensic Science Area and the development of forensic science infrastructure in Europe ${ }^{1}$ ).

Creating a European forensic space and forensic infrastructure development in Europe by 2020 (EFSA 2020). In order to make the most efficient and effective conduct of criminal investigations in the European Union, the Council of the European Union has issued the mentioned document with the aim of ensuring that criminal-forensic investigations received in one country can be applied without restraint in other European Union countries and that forensic evidence obtained in one country applies in all EU countries. In this document, it is emphasized that EUROPOL ${ }^{2}$, in the course of criminal investigations conducted in the European Union, uses the forensic results obtained in different countries regarding the same criminal offense. This means that criminal-forensic investigations in the European Union (but also in other European countries) must be standardized, harmonized, matching and uniform. Concerning the mentioned and for the realization of facilitating interstate cooperation in the field of forensic science, improving the quality of forensic investigations, improving the cooperation of the judicial system and forensic institutions, emphasizing the need to accept the minimum forensic scientific standards in the collection, processing and use of forensic data, the Council of the European Union mentioned document imperatively imposed on Member States, by 2020, to standardize and harmonize forensic affairs, achieving the following goals:

1 URL: https://www.consilium.europa.eu/uedocs/cms_data/docs/pressdata/en/ jha/126875.pdf.

2 URL: https://www.europol.europa.eu/. 
- supporting and facilitating the cooperation of EU Member States in the field of forensic science, as well as interstate exchange of forensic data;

- supporting the development of cooperation between the judicial institutions of the European Union countries, and in particular the development of cooperation between forensic laboratories.

The stated goals will be achieved by the Member States by meeting the following tasks:

1. Determining the contact of an institution or person in its own country that will be responsible for the implementation and realization of the EFSA 2020 project;

2. The said contact institution or person should provide coordination between forensic institutions and all other relevant institutions that use forensic results (judiciary, police and others). This is because of the guarantee that the activities of the EFSA 2020 project will be properly monitored and treated at the national level.

3. Developing cooperation with European institutions dealing with criminalforensic investigations, such as ENFSI and EUROPOL.

4. Accreditation of forensic institutions in the European Union and European countries. The European Commission, through the ENFSI, should develop an action plan to encourage voluntary accreditation of forensic laboratories, focusing on those areas in which potentially international-level information is produced, such as areas related to firearms and ammunition, explosives and drugs, which are at the informal meeting of the ministers of the PUP on January 26, 2016 highlighted as priorities. In addition to the "traditional" forensics, it imposed a necessary exchange of reliable digital forensic data that can be used as evidence in a court other than the jurisdiction of the Member State from which they originate. Accreditation of forensic procedures should therefore be considered as a priority in this area.

5. Respecting the minimum expertise of employees in forensic institutions. This action seeks to encourage the development and use of forensic information training courses for police officers, forensic experts, emergency services, prosecutors and judges. The aim of these courses should be to raise the general level of awareness about forensics, but they should be adapted for specific forensic sciences, for example, digital forensics or forensic DNA analysis. Learning can take place through traditional courses, e-learning, applications, online seminars, etc.

6. Creation of standardized and uniform instructions for work in certain fields of forensic research, research and expertise in the countries of Europe. This is the right way for forensics in all European countries to work in the same, standardized and uniform way².

1 URL: http://data.consilium.europa.eu/doc/document/ST-9798-2016-INIT/hr/pdf.

2 In 2016, ENFSI developed the Best Practice Manual as a kind of instruction from ten forensic areas (forensic processing of fires, manuscripts, explosives, biological traces, DNA traces, fingerprints, hair traces, traces of traffic accidents, traces of firearms weapons and expertise in digital evidence). In this way it is achieved that all forensics in Europe work in a uniform, standardized, uniform and unified manner. These instructions are available at URL: http://enfsi.eu/documents/best-practice-manuals/. 
7. Inclusion of all forensic institutions, in the countries of Europe, inter-laboratory checks and tests of competence. These tests are done at least once by a gentleman and serve as a guarantor that a concrete forensic institution receives results that are valid and internationally recognized.

8. Apply forensic standards to the crime scene and establish the so-called chain of samples custody from the very spot to the courtroom.

9. Creation, updating and optimization of forensic databases at the European Union level. It is important to note that at the level of the European Union, an interstate database of forensic data has already been created, in the field of DNA tracing and traces of papillary lines, which has the name Prussian agreement ${ }^{1}$ or the Primacy Act. ENFSI is working on the project: "Adopting the development of pan-European databases in the field of forensic science", supported by the European Commission (label: HOME/2014/ISPP/AG/ENFSI/4000007822).

10. Strengthening and developing forensic awareness, in particular through education and training in this field towards persons who are not forensics, but in their work use the results obtained by criminal-forensic investigations (judges, prosecutors, lawyers).

Conclusion. Forensic research, investigation and expert work is one of the most important, if not the most important, segments of criminal investigations of cross-border crime, terrorism and corruption. As contemporary crime does not recognize borders, the contemporary fight against various forms of crime must be carried out in conditions of unquestioning interstate cooperation and co-ordination. In order for this cooperation and coordination to be operational, efficient and purposeful, interstate agencies dealing with crime investigation operations must be in direct cooperation. The condition of the mentioned cooperation must be the

1 On May 27, 2005, in the city of Prum in the Federal Republic of Germany, the seven countries of the European Union (Austria, Belgium, France, Germany, Luxembourg, Netherlands and Spain) signed an agreement that, among other things, allows for a more successful fight against terrorism, and the exchange of DNA profiles and fingerprints. Each State Party to the agreement has been granted access to DNA records and fingerprint records of all other States Parties to the agreement. Following the adoption of the decision of the Council of the European Union in 2008, the Prue Agreement became the law of the European Union. Each state of the European Union must therefore establish a DNA record and prepare specific legal regulations that will govern its conduct. By April 2010, the DNA registers of Austria, Spain, Germany, Belgium, Luxembourg, France, Finland, Slovenia, Hungary, Netherlands, Estonia, Romania and Italy had already been linked to the following countries of the European Union: Portugal, Greece, Sweden, Bulgaria and Slovakia. The exchange of DNA traces of traces runs every day, the number of identifications of biological traces of human origin and the perpetrators of crimes is much higher than expected. An important role has also been played by ENFSI here. The ENFSI-set of DNA molecules, which should contain the DNA profile, has become the European standard set, and the working group of DNA experts in the ENFSI has prepared a guide to keeping DNA records. In 2009, fingerprint records to the computer systems of AFIS - Austria, Germany, Luxembourg and Slovenia were also connected (URL: http://www.thefreedictionary.com/ $\operatorname{Pr} \% \mathrm{C} 3 \% \mathrm{BCm}+$ Agreement). 
standardization and harmonization of criminal-forensic investigations. Standardization and harmonization of criminal-forensic investigation work is carried out through the accreditation of forensic institutions. Accreditation in Criminal Law and Criminology is a guarantor of raising the level of organizational and technical competence for the work of the criminal-forensic institution. The goals of the development of forensic laboratories are related to the integration into the international standardization and accreditation system for the purpose of controlling all evidence-gathering activities in criminal proceedings. This means that the entire process of dealing with traces in the criminalist should be such as to exclude the possibility of contamination, compromise, alteration and distortion of the trail itself. Accreditation, and therefore standardization and harmonization of forensic institutes in the state of Europe, are performed through the ENFSI association. The said association implements and controls the application of EU legislation in the field of forensic research, research and expertise. In line with the Decision of the Council of the European Union 2009/905/JHA, ENFSI accredited forensic institutions in accordance with ISO 17025 standard in its European countries (except Portugal, Bosnia and Herzegovina, Albania, Moldova and Belarus). Thus, forensic work has been standardized and agreed, so evidence obtained by forensic and criminal investigations in one country of Europe can be operational and processed in all other countries. Furthermore, ENFSI is currently working on the European Union project Creation of a European Forensic Area and the development of Forensic Infrastructure in Europe by 2020. With the successful implementation of this project it will be in all the countries of Europe (meeting the demanding standards of the project, which will be controlled by the ENFSI) When managing and conducting criminal investigations, forensic evidence is obtained in an equal, standardized and harmonized way.

It is useful to mention at the end of the work that the realization of the European Union project The creation of a European Forensic Area and the development of forensic infrastructure in Europe by 2020 is not very easy and simple in practice. The Director of the Forensic Institute of the Federal Criminal Police (Bundeskriminalamt) in Wiesbaden (Germany) wrote to the European Commission $^{1}$ that the problems that will be shown in practice during the implementation of this project will be mentioned in the letter. Firstly, it is said that it is very difficult (even unrealistic) that by 2020 they accredit all the methods in a forensic laboratory. This is because the accreditation is a long-lasting process that requires a great deal of working time forensics and a great deal of labour intake. As a suggestion for overcoming, it is proposed to accredit methods such as DNA and dactyloscopy (for the reason of the existing international databases of these forensic methods), and for other methods, if not accredited, to develop operational procedure standards (SOPs) and to regularly participates in inter-laboratory checks. In the part of the project's goal of respecting the minimum of expertise of employees in forensic institutions, the certification of employees in forensic laboratories is proposed. The certification program should be common in all

${ }^{1}$ Andermann T. Questionnaire on the European Forensic Science Area 2020. 2015. 
European countries and be controlled and checked by appropriate experts from the ENFSI. At the end of the work, we propose that all forensic workers in Europe have to train in the direction of education and training from a specific area of forensics, in the same way, and for the training and study plan and final assessment of the knowledge should be responsible to the ENFSI.

\section{Literature}

1. Caddy B., Thorpe J. W. Communication Skills and Expertise in the Inquisitorial and Adversarial Legal System. ENFSI Meeting Madrid. 1998.

2. Council of the Europe (2009). EU Council Framework Decision 2009/905/ JHA of 30th November 2009: Accreditation of forensic service. URL: http:// eclan.eu/en/eu-legislatory/.

3. Council of the Europe (2011). EFSA 2020 (Council conclusions on the vision for European Forensic Science 2020 including the creation of a European Forensic Science Area and the development of forensic science infrastructure in Europe. URL: http://www.consilium.europa.eu/uedocs/cms_data/docs/ pressdata/en/jha/126875.pdf.

4. Maver D. Integritet materijalnih dokaza. Pravo i forenzika u kriminalistici: Zbornik radova. Kriminalističko policijska akademija (editor prof. D. Vasiljević). 2009. P. 31-37.

5. ENFSI-EA (European co-operation for Accreditation). Guide for the implementation of ISO/IEC 17020 in the crime. 2008.

6. Golja J. Kriminalistično tehnični dokaz. Posvet dokazovanje v težkih primerih. UNI Maribor, 2007.

7. Green R. Forensic investigation in the UK. V: Newburn. Williamson, Wright: Handbook of Criminal Investigation. Willan.

8. ILAC (2014) Modules in a Forensic Science Process. URL: http://ilac.org/ latest_ilac_news/ilac-g19082014-published/.

9. Ivanovic A., Ragozin V., Vucinic D. Advocacy for accreditation of the forensic laboratories of the western balkan countries in ISO/IEC 17025:2011 and enhancement of their mutual cooperation. Criminal Justice and Security in Central and Eastern Europe: Safety, Security, and Social Control in Local Communities (editor proof dr G. Mesko, proof dr B. Lobnikar). 2016.

10. Ivanović A., Merike Rump. Accreditation process forensic center of Montenegro to the mentorship of the European Union (Projects EMFA-2). 10 ${ }^{\text {th }}$ Symposium of forensic sciences. Bratislava, 2011. Symposium Journal. Kriminalisticky a expertizny ustav Policajneho zboru.

11. Bencivenga P. Which Standards Are Standard? Differences between ISO/IEC 17025 and 17020 for forensic agencies. Forensic Magazine 10/22/2015. Publishing, 2007 (p. 338-356) scene investigation work. Request for Contribution. Communication CM 3080/15.

12. Simonović B. Standardizacija i akreditacija kao jedan od načina profesionalizacije policijske i kriminalističke službe. Bezbednost. Beograd. MUP Srbije. No 1-2/2009. P. 236-254.

13. Andermann T. Questionnaire on the European Forensic Science Area 2020. 2015. 
14. Majstorović V., Majkić-Singh N. Akreditovana laboratorija kao model za unapređenje kvaliteta u organizaciji. Jugoslov Med Biohem. 2006. 25. P. 1-9.

\section{РАЗВИТИЕ И ВЗАИМОДЕЙСТВИЕ СУДЕБНО-ЭКСПЕРТНЫХ УЧРЕЖДЕНИЙ В ЕВРОПЕ: СОВРЕМЕННЫЙ АСПЕКТ}

\section{А. Иванович}

Рассмотрен метод стандартизации и аккредитацуии судебно-экспертной деятельности как один из наиболее важных сегментов в раскрытии уголовных преступлений и выявлении преступников. Во время уголовных расследований, в случаях трансграничной преступности, терроризма и коррупиии, очень важно правильно использовать доказательства, полученные в другой стране. В этом направлении представлен обзор процессов гармонизации результатов судебно-экспертных работ в странах Европы, в основном связанных с решением Совета ЕС 2009/905/JНА об аккредитаџии судебно-экспертных служб, и проведения лабораторной деятельности в унифицированной, стандартизированной и единообразной форме для судебно-экспертных исследований, а также проектом Европейского Союза «О создании к 2020 году европейского судебно-экспертного пространства и развитии судебно-экспертной инфраструктуры в Европе», который должен быть завершен во всех странах ЕС к 2020 г.

Указанные в проекте иели будут достигнуты государствами-членами ЕС путем решения таких основных задач: 1. Установление контакта с учреждением или лицом в конкретной стране, которое будет отвечать за имплементацию и реализаџию проекта EFSA 2020. 2. Развитие сотрудничества с европейскими институтами, занимающимися уголовными судебно-экспертными исследованиями, такими как ENFSI и EUROPOL (Европол). 3. Аккредитация судебно-экспертных учреждений в Европейском Союзе и в других европейских странах. Европейская комиссия через ENFSI должна разработать план действий по поощрению добровольной аккредитаџии судебно-экспертных лабораторий. 4. Поощрение разработки и использования курсов судебно-экспертной информационной подготовки для сотрудников полищии, судебных экспертов, служб экстренной помощи, прокуроров и судей. 5. Создание стандартизированных и единообразных инструкиий для работы в определенных областях судебно-экспертных исследований в странах Eвропьы. 6. Включение всех судебно-экспертных учреждений стран Европы в межлабораторные проверки и тесты на компетентность. 7. Применение судебно-экспертных стандартов к месту преступления, чтобы создать так называемую иееь обеспечения сохранности образиов от места происшествия до зала суда. 8. Создание, обновление и оптимизация судебно-экспертных баз данных на уровне Европейского Союза. 9. Укрепление и развитие судебно-экспертной осведомленности, в частности, посредством обучения и подготовки в этой области лии, которые не являются судебными экспертами, но в своей работе используют результаты судебно-экспертных исследований (судей, прокуроров, адвокатов). При условии успешной реализации этого проекта он будет действовать во всех странах Eвропь.

Ключевые слова: судебная экспертиза, уголовное расследование, аккредитация, стандартизация. 


\section{РОЗВИТОК І ВЗАЄМОДІЯ \\ СУДОВО-ЕКСПЕРТНИХ УСТАНОВ У СВРОПІ: СУЧАСНИЙ АСПЕКТ}

\section{А. Іванович}

Розглянуто метод стандартизаиії й акредитаиії судово-експертної діяльності як один із найбільш важливих сегментів у розкритті кримінальних злочинів і виявленні злочинців. Під час кримінальних розслідувань, у випадках транскордонної злочинності, тероризму и корупиії, дуже важливо правильно використовувати докази, отримані в іншій краӥні. У иъьому напрямі надано огляд процесів гармонізаиії результатів судово-експертних робіт у краӥнах Європи, в основному пов'язаних із рішенням Ради СС 2009/905/JНА про акредитацію судово-експертних служб і проведення лабораторної діяльності в уніфікованій, стандартизованій $і$ одноманітній формі для судово-експертних досліджень, а також проектом Європейського Союзу «Про створення до 2020 року європейського судово-експертного простору й розвитку судово-експертної інфраструктури в Свропі», який повинен бути завершений у всіх країнах ЄC до 2020 p.

Зазначені в проекті иұілі будуть досягнуті державами-членами ЕС шляхом вирішення таких основних завдань: 1. Установлення контакту з установою або особою в конкретній краӥні, яка буде відповідати за імплементачію та реалізаџію проекту EFSA 2020. 2. Розвиток співробітництва з європейськими інститутами, що займаються судово-експертними дослідженнями, такими як ENFSI та EUROPOL (Европол). 3. Акредитаиії судово-експертних установ у Європейському Союзі й у інших європейських країнах. Свропейська комісія через ENFSI повинна розробити план дій із заохочення добровільної акредитаџії судово-експертних лабораторій. 4. Заохочення до розроблення й використання курсів судово-експертної інформаційної підготовки для співробітників поліщії, судових експертів, служб екстреної допомоги, прокурорів і суддів. 5. Створення стандартизованих і однакових інструкиій для роботи в певних галузях судово-експертних досліджень у краӥнах Європи. б. Включення всіх судово-експертних установ країн Свропи в міжлабораторні перевірки й тести на компетентність. 7. Застосування судовоекспертних стандартів до місия злочину, щоб створити так званий ланиюг забезпечення збереження зразків від місия події до залу суду. 8. Створення, відновлення й оптимізаиія судово-експертних баз даних на рівні Європейського Союзу. 9. Змічнення й розвиток судово-експертної поінформованості, зокрема, за допомогою створення й підготовки в цій галузі осіб, які не є судовими експертами, але у своій роботі використовують результати судово-експертних досліджень (суддів, прокурорів, адвокатів). За умови успішної реалізаиії цього проекту він буде діяти в усіх країнах Свропи.

Ключові слова: судова експертиза, кримінальне розслідування, акредитаиія, стандартизаиія. 